\title{
Hepatocellular response to acute kidney injury in the critically ill: serum induces CYP2D6 transcription
}

\author{
K Lane ${ }^{1,2^{*}}$, JJ Dixon ${ }^{1,2}$, IAM MacPhee ${ }^{3}$, BJ Philips ${ }^{2,4}$, M Dockrell $^{5}$ \\ From ESICM LIVES 2015 \\ Berlin, Germany. 3-7 October 2015
}

\section{Introduction}

Cytochrome P450 2D6 (CYP2D6) is a clinically important CYP, metabolising approximately $25 \%$ common drugs. We investigated the clinical effect of acute kidney injury (AKI) on hepatic CYP2D6 metabolism in critically ill adults, using the probe drug tramadol (abstract 470). We found no effect of AKI but a strong CYP2D6 genotype/phenotype influence on tramadol metabolism.

Rodent studies indicate no change or impaired CYP2D6 metabolism in chronic kidney disease and AKI (Refs [1-3]). No published human or animal data has examined CYP2D6 transcription, translation or activity in AKI. Previously we demonstrated no change in CYP2D6 transcription when pooled serum from patients with end-stage kidney disease (ESKD) was applied to human HepG2 cells, known to express the functional CYP2D6*1 allele.

\section{Objectives}

We aimed to determine whether a transcriptional change occurred in CYP2D6 expression when hepatocytes are exposed to serum from critically ill patients with and without AKI.

\section{Methods}

As part of a clinical study of hepatic drug metabolism in AKI, serum from critically ill adult patients was stored at $-80^{\circ} \mathrm{C}$. Serum from 16 patients with the severest AKI (KDIGO 3, not yet on renal replacement, highest foldchange in serum creatinine) was compared to that of 15 critically ill controls without AKI. HepG2 cells (human hepatoma cell line) were exposed to medium with $10 \%$ individual human serum in separate wells for $24 \mathrm{~h}$, then lysed. CYP2D6 gene expression was examined by real

${ }^{1}$ St George's University Hospitals NHS Foundation Trust, Critical Care, London, United Kingdom

Full list of author information is available at the end of the article time reverse transcriptase quantitative PCR (q-rt-RTPCR). Statistical analysis was performed using Biorad CFX 3.1 Software.

\section{Results}

The patient demographics are shown.

Cells displayed no obvious morphological differences.

An increase in relative CYP2D6 transcription occurred (1.14 vs $1.00, \mathrm{p}=0.037)$ when cells were exposed to serum from individual patients with AKI compared to those without.

\section{Conclusions}

In contrast to the clinical study finding that CYP2D6 metabolism is not altered by AKI, a significant change in

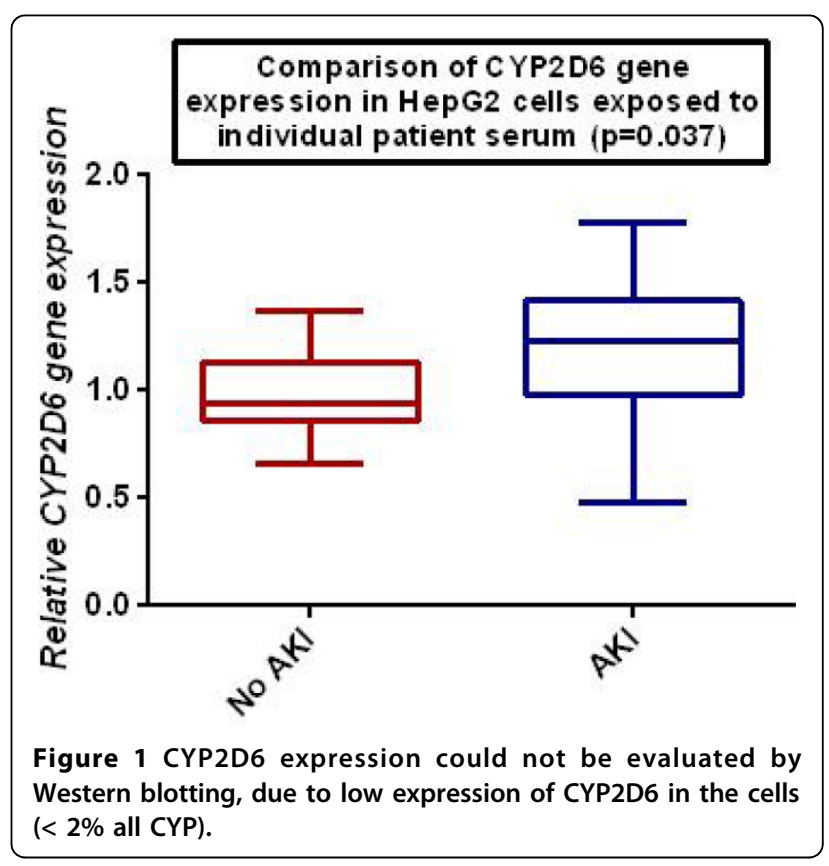


Table 1. Patient Demographics for Critically III

\begin{tabular}{lll}
\hline Value - Median [range] & Critically III, no AKI ( $\mathbf{n = 1 5 )}$ (KDIGO 0) & Critically III, Severe AKI (n=16) (KDIGO 3) \\
\hline Age $(\mathrm{y})$ & $77(22-88)$ & $58.5(19-73)$ \\
\hline Sex F:M & $7: 8$ & $4: 12$ \\
\hline APACHE II score & $20(5-25)$ & $25(13-27)$ \\
\hline SOFA score & $7(1-11)$ & $7(3-14)$ \\
\hline Baseline Serum Creatinine (umol/L) & $85(58-112)$ & $73(46-114)$ \\
\hline Fold change in Serum Creat from Baseline on study day & $0.97(0.5-1.16)$ & $3.87(3.1-10.1)$ \\
\hline Serum Creatinine when studied (umol/L) & $79(41-131)$ & $304(157-595)$ \\
\hline Cellular Confluence at Harvest (\%) & $86(80-90)$ & $85(80-90)$ \\
\hline Tramadol] ((T4-T0) $(\mathrm{ng} / \mathrm{mL})$ [All genotypes included] & $23.5(14.3-39.8)$ & $30.0(11.7-41.4)$ \\
\hline
\end{tabular}

increase mRNA transcription occurred when sera were individually tested. The functionality of this transcript is uncertain and whether it translates into increased cellular CYP2D6 protein concentration in AKI remains unknown.

\title{
Grant Acknowledgment
}

ESICM Basic Sciences Award, Springer Foundation and St George's Medical Charity.

\author{
Authors' details \\ Research, Surrey, United Kingdom. \\ Published: 1 October 2015

\section{References} \\ 1. Okabe $H$, et al: Biol Pharm Bull 2004, 27:1422-1427. \\ 2. Okabe H, et al: Pharm Res 2003, 20:1591-1594. \\ 3. Tanabe $H$, et al: Biol Pharm Bull 2007, 30:552-555.
}

'St George's University Hospitals NHS Foundation Trust, Critical Care, London, United Kingdom. ${ }^{2}$ St George's University of London, Critical Care, London, United Kingdom. ${ }^{3}$ St George's University of London, Renal Medicine, London, United Kingdom. ${ }^{4}$ St George's University Hospitals NHS Foundation Trust, London, United Kingdom. ${ }^{5}$ South West Thames Institute for Renal

\section{Submit your manuscript to a SpringerOpen ${ }^{\mathcal{O}}$ journal and benefit from:}

- Convenient online submission

- Rigorous peer review

- Immediate publication on acceptance

- Open access: articles freely available online

- High visibility within the field

- Retaining the copyright to your article

Submit your next manuscript at $>$ springeropen.com 